\title{
Correction to: Confusions about 'Inner' and 'Outer' Voices: Conceptual Problems in the Study of Auditory Verbal Hallucinations
}

\author{
Franz Knappik ${ }^{1}$ (D) Josef J. Bless ${ }^{2}$ (D) $\cdot$ Frank Larøi $^{2}$ (D) \\ Published online: 13 March 2021 \\ (C) The Author(s) 2021
}

\section{Correction to: Review of Philosophy and Psychology https://doi.org/10.1007/s13164-021-00532-x}

The affiliation of the third author was incorrect in the initial online publication. The original article has been corrected.

Publisher's Note Springer Nature remains neutral with regard to jurisdictional claims in published maps and institutional affiliations.

The online version of the original article can be found at https://doi.org/10.1007/s13164-021-00532-x

\author{
Franz Knappik \\ franz.knappik@uib.no \\ Josef J. Bless \\ josef.bless@uib.no \\ Frank Larøi \\ frank.laroi@uib.no
}

1 Department of Philosophy, University of Bergen, Sydnesplassen 12/13, 5020 Bergen, Norway

2 Department of Biological and Medical Psychology, University of Bergen, Jonas Lies vei 91, 5020 Bergen, Norway 